\title{
Development potential of Russian zirconium industry on world markets
}

\author{
Fedoseev S.
}

Tcvetkov P.

Saint-Petersburg Mining University, Saint Petersburg, Russia

Sidorov N.

Saint- Petersburg State Transport University, Saint Petersburg, Russia

\section{Keywords}

Zirconium, baddeleyite, minerals, zircon, production, consumption

\begin{abstract}
The review describes the most commonly natural minerals and compounds, which contains zirconium and the structure of zirconium-containing materials consumption in the modern conditions. Substitutes of zirconium products in individual industries are identified. A brief analysis of Russian mineral resources base of zirconium shows the most promising fields and regions with considerable resource potential for the development of zirconium production. An analysis of the volume and structure of world reserves of zirconium identified the major importers and exporters. The analysis of trends in production and consumption of zirconium in Russia and in the world markets showed a high elasticity of zirconium products demand by the price. It is shown that Russia, despite the availability of resources, is dependent on the import of zirconium.

The article presents the forecast of zirconium production and consumption in the world market, which shows the necessity of Russian zirconium industry development to enter international markets and meet the needs of the country.
\end{abstract}

Corresponding author: Tcvetkov $P$

Email address for corresponding author: pscvetkov@spmi.ru

First submission received: 12th March 2017

Revised submission received:10th May 2017

Accepted: 17th June 2017

\begin{abstract}
Acknowledgements
This paper is based on research carried out with the financial support of the grant of the Russian Science Foundation «The purpose-oriented complex program of the Russian Arctic development (project №14-38-00009) ». Peter the Great St. Petersburg Polytechnic University
\end{abstract}

\section{Introduction}

Russian economy is characterized by low level of industrial development, expressed in the absence of capacities for deep processing of mineral raw materials. The presence of only primary processing capacity determines the current way of development - export of raw mineral resources with a minimum value-added (Vyboldina et al. 2016). As a result, Russia imports exported raw materials, which processed in foreign factories. It is also common situation when, having sufficient production capacity, all manufactured products are exported because of more attractive prices, and domestic demand is met by import (Didenko et al. 2015).

An example of this is the situation in the market of zirconium products, which, despite the relatively low volume of production capacities (world production in $2014-1.51$ million tons), is a strategic resource for a number of industries.

\section{Zirconium products application areas}

Zirconium - non-ferrous metal, which, despite its substantial world reserves, often referred to a group of rare-earth minerals due to its high rate of decentralization in the earth's crust. Zirconium is not found in its pure form in nature, however, there are about 40 minerals which are contain 
zirconium in the form of oxides or salts, the most common of them are baddeleyite ( $\mathrm{ZrO} 2)$, and zircon ( $\mathrm{ZrSiO} 4)$ (Volpato et al. 2011). Zirconium applications are quite extensive, due to its high abrasion resistance, thermal conductivity, low rate of interaction with other metals, and so forth (Saridag et al. 2013).

The main application area of zirconium use is ceramic production (53.4\%). Another application areas are: foundry industry $(13.6 \%)$, the manufacture of refractory bricks and other refractory materials $(12.6 \%)$, chemical industry $(14.8 \%)$, nuclear power $(0.5 \%)$, electronics $(3 \%)$, and others. (2.1\%) (Lundberg 2011).

Taking into consideration high price of zirconium, in some industries there is a tendency to use its substitutes (Elsner 2015):

- in manufacture of refractory materials: bauxite, chromite, graphite, magnesite, olivine, sillimanite, etc;

- in foundry industry: bauxite, aluminum, chromium, clay, olivine, perlite, silica sand, vermiculite;

- in manufacture of abrasives: feldspar, magnetite, hematite, pumice, perlite, ilmenite and others.

However, there are no substitutes for about $80 \%$ of zirconium products markets, for example, nuclear power energy, where zircon is the main component for the production of alloys used for the manufacture of fuel rods cladding (Macdonald 2011, Thomson Reuters 2009).

\section{Russian zirconium reserves}

Russia has significant resources of zirconium - 11.6 million tons. The reserves are estimated at 12.3 million tons According to this Russia takes the third place in the world (USGS 2015). The largest reserves of zirconium have Australia $(31.86 \%)$ and South Africa $(8.74 \%)$. The shares of Ukraine, the USA, India and Brazil account between 1-3\% of world reserves.

Russian state balance considers 17 fields of zirconium, of which 11 fields - placer, 5 - primary, 1 - anthropogenic. The most promising fields in terms of mineral reserves volume are (Akimova et al. 2014, Larichkin et al. 2013):

Kovdor carbonatite primary deposit (Murmansk region). Now being developed by JSC "Kovdor GOK". Reserves of deposit are estimated at 1.2 million tons (10\% of total Russian reserves). In 2013, after prospecting, the reserves of baddeleyite-apatite-magnetite ore were increased by 994.2 thousand tons (7\% of the total Russian reserves). Total reserves of the Kovdor deposit is 2.34 million tons ( $20 \%$ of total Russian reserves). The average content of $\mathrm{ZrO} 2$ in the ore is $0.15 \%$.

"Tuganskoe" placer deposit (Tomsk region). Now being developed by JSC "Tuganskiy GOK "Ilmenite". Reserves of zircon-rutile-ilmenite ores are estimated at 980.5 thousand tons (8.5\% of total reserves). The content of $\mathrm{ZrO} 2$ is $7.72 \mathrm{k} . / \mathrm{m} 3$.

"Central" placer deposit (Tambov region). Reserves of zircon-rutile-ilmenite ores are estimated at 830.2 thousand tons. The content of $\mathrm{ZrO} 2$ is $3-6.5 \mathrm{k} . / \mathrm{m} 3$.

"Lukyanovskoe" zircon-rutile-ilmenite placer deposit (Nizhny Novgorod region). Reserves are estimated at 346.4 thousand tons. This field contains the richest zircon ore in Russia - $\mathrm{ZrO} 2$ content is $13 \mathrm{k} . / \mathrm{m} 3$.

"Katuginskoe" zircon-pyrochlore-cryolite primary deposit (Chita Region). The share of this deposit reserves is 3\% (361.2 tons) of the total Russian reserves. Resources are estimated at 3 million tons. Average content of $\mathrm{ZrO} 2$ in the ore is $1.58 \%$.

"Ulug-Tanzekskoe" zircon-columbite-pyrochlore primary deposit (Tyva Republic) refers to the undistributed fund. Reserves are estimated at 1.9 million tons. Resources -2.8 million tons. The average content of $\mathrm{ZrO} 2$ in the ore is $0.4 \%$.

Lovozero rare-metal deposit. $\mathrm{ZrO} 2$ content in apatite-nepheline-syenite ores (Alluayv area) ranges from $1.83 \%$ to $5-9 \%$, and the total reserves are estimated at 7.28 million tons 
Thus, most of Russian zirconium reserves are concentrated in refractory ores. Placer deposits containing easy to process ores comprise only $28 \%$ of the country resources and tend to have a sufficiently large depth and a low content of $\mathrm{ZrO} 2$.

Despite significant reserves of zirconium, the share of Russia in its global production was only $0.6 \%$ ( 8273 tons) in 2013 . The world's largest production facilities to produce zirconium are in Australia (38.5\%) and South Africa (23.13\%). A significant role in world production playing three countries: The United States $(7.4 \%)$, Indonesia $(7.7 \%)$ and China $(8.99 \%$ of world production, having only $0.5 \%$ of the world resources) (RiC2014, Reihl et al. 2014). At the same time on the territory of China are located $88 \%$ of the world's chemical production capacity for zirconium refining (Macdonald 2014).

In Russia, almost $100 \%$ of zirconium is produced by JSC "Kovdorskiy GOK", where a comprehensive production and processing of baddeleyite-apatite-magnetite ores and anthropogenic deposit was implemented to produce baddeleyite concentrate. These ores are extremely valuable, because the cost of zirconium production from them is the lowest. Today JSC "Kovdorskiy GOK" is the only one producer of baddeleyite concentrate in the world. Other reserves of baddeleyite were only in South Africa (Phalaborwa deposit), but they were completely exhausted by 2001.

In 2013, on Tugansk deposit was launched pilot production line of zircon concentrate production. As a result, was obtained 121 tons of zircon concentrate after processing of 47.7 tons of sand ore.

In addition to these fields, there is a significant resource potential for the development of Russian zirconium industry discussed in detail in Larichkin's paper (Larichkin et al. 2013). Among the promising areas of production are Volga region of Siberia, Baikal, Tambov, Nizhny Novgorod and Stavropol regions.

\section{Global zirconium reserves}

Russia is the third world producer of zirconium and its alloys products and occupies $18 \%$ of the world market. Zirconium processing enterprises are in the Republic of Udmurtia, Moscow, Perm, Leningrad Region, the Sverdlovsk region and other regions. Among the products of Russian enterprises: metal zirconium, zirconium-based alloys, ceramics, refractories, etc.

Export of zirconium from Russia (in Europe, Japan, China and the United States and other countries) in 2013 was $95 \%$ of total production. At the same time, domestic demand for zirconium in 2013 was about 8.2 tons. Thus, the domestic needs were satisfied exclusively by import ( 8 tons in 2013), mainly from Ukraine. In current political climate, this source of raw materials is questionable, and its volume did not allow Russia to meet the needs of more than $25-50 \%$.

According to Metal Research (Zirconium market 2012), in 2010 the largest importers of zirconium in Russia were: "Trans Pogran services" (26\%), TD "Hercules" (25\%) and "Belkhi" (17\%). Other companies together occupy about $32 \%$ of total import.

The world's largest importers of zirconium are European countries (Spain (100 thousand tons), Italy (56.57 thousand tons), France (27.05 thousand tons), Germany (26.65 thousand tons) Belgium (17.03 thousand tons), the UK (7.49 thousand tons) (BGS 2015)), as well as China and Japan (Porter 2014). In 2013, more than $85 \%$ of mined and processed zirconium at the production facilities in China were exported to Japan, the USA and Europe (Tiwari 2014). However, due to the decline of demand in China, the volume of zirconium products export fell. Thus, the volume of US import in 2013 fell in comparison with 2012 by 61.1\% (Sutton 2015) (51.8\% according to USGS (2015)) and amounted to 6.5 tons (8.05 thousand tons according to USGS (2015)).

The world's largest mining companies (in zirconium industry) are Iluka Resources Ltd (Australia, the USA), Richards Bay Minerals (South Africa), Exxaro (South Africa). Respectively their shares accounted for $34 \%, 18 \%$ and $15 \%$ of the world zirconium production (Lundberg 2011). Extraction of these companies carried out, mostly, on the placer deposits of zirconium (95\%). 
Demand for zirconium is characterized by high price elasticity. According to the DERA (2012) statistical data we can say that in the period from 2005 to 2011 the balance on zirconium markets ranged from a deficit of 86.9 tons (2008), to a surplus of 300.7 tons (2011). At the same time, zirconium markets have a quite slow response to the impact of external macroeconomic factors. It confirmed by international economic crisis (2009), after which the surplus amounted to 157 thousand tons (more than half of demand rise was in Indonesia).

According to the State report on the status and use of mineral resources of Russian Federation in 2013 and "Mineral IAC" (2016) the average prices for zircon concentrate in 2011 was reached 1800-2400 USD/t. (2-2.5 times higher than in 2010), depending on the zirconium content and country of origin. At the same time, the price of baddeleyite increased slightly - from $3250 \mathrm{USD} / \mathrm{t}$. up to $3350 \mathrm{USD} / \mathrm{t}$. This situation has led to an increase in sales of baddeleyite concentrate of "Kovdorskiy GOK" on 3 thousand tons (30 \%). However, in 2013, due to the reduction in demand for zirconia in China and the expansion of the substitutes markets, the price dropped to $1450 \mathrm{USD} / \mathrm{t}$., and in 2015 to 1058 USD/t. (Figure 1).

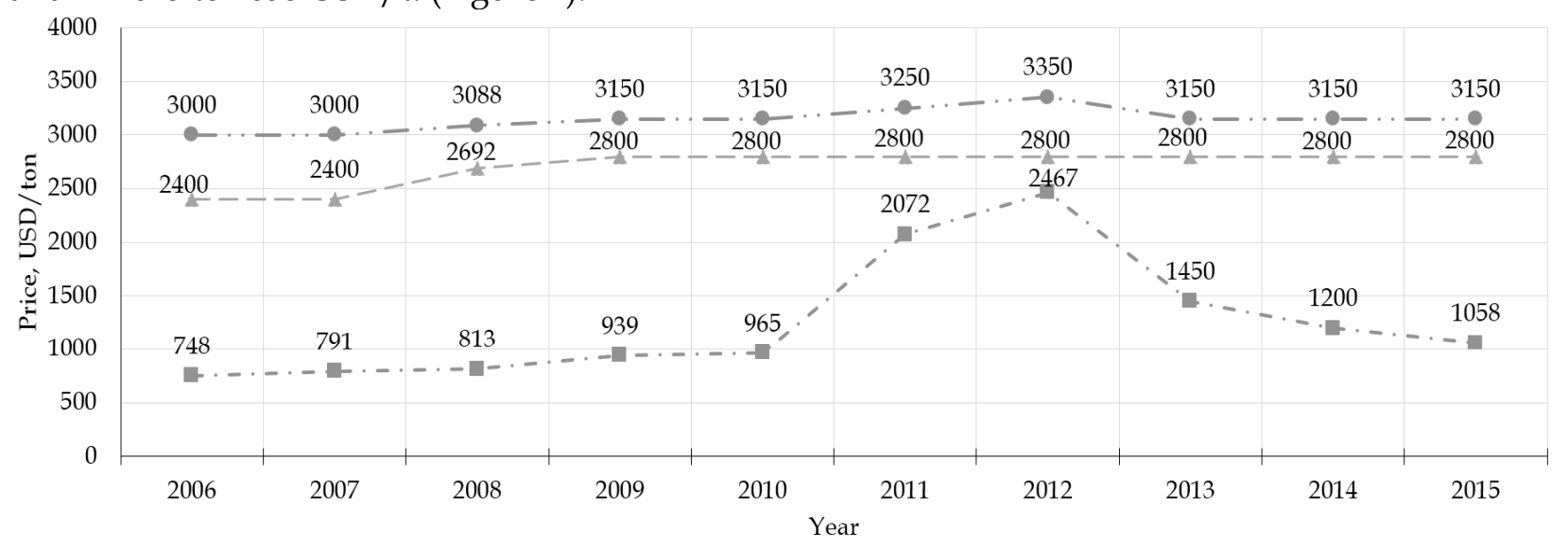

- Zirconium concentrate $(66 \% \mathrm{ZrO} 2)$ of the Australian producers $\rightarrow$ Baddeleyite concentrate (ceramic type)
- - Baddeleyite concentrate (refractory / abrasive type)

Figure 1. The dynamic of Zirconium and Baddeleyite prices in 2006-2015

\section{The development potential of the global Zirconium Industry}

In recent years, many companies actively work to start implementation of zirconium mining projects in Australia, Mozambique, Tanzania, Madagascar and other countries. For example, in 2016 it is planned to launch the project Dubbo Zirconia (New South Wales, Australia). Estimated field life period - 20 years. Annual production capacity of zircon - 16 thousand tons. Furthermore, it is expected to produce niobium, tantalum, yttrium, hafnium and other rare earth elements as byproducts (Chalmers 2012).

In 2014 the development of three major placer deposits were launched. The first one is Tormina project (South Africa), mine «Xolobeni». Start of production occurred in February 2014. The mine life period with annual production capacity of 48 thousand tons (the content of $\mathrm{ZrO} 2-81 \%$ ) is 4 years (EIR 2015).

The second is Kwale project (Kenya), launched in February 2014. Production of zircon, is expected to be around 30 tons per year. The field life period will be 13 years (Bwye 2014).

The third is «Grand Cote» project (Senegal), launched in August 2014. The annual production capacity is 80 thousand tons of zircon per year. The field life period is more than 20 years (Staff and Munatswa 2014, Stephenson 2010). 
Thus, despite the current surplus of zirconium products and the drop of demand caused by artificially high prices for zircon in 2011-2012, which is observed till now, according to Credit Suisse (Deverel et al. 2013), the world enterprises continue to grow capacity of zircon extraction and processing. The reliability of such projects is provided by the complex character of ores (contain several useful components except zirconium), from which the production of zirconium is planned.

According to MacDonald and Chalsmer (2013), in spite of a certain imbalance of supply and demand, the need for zirconium is growing annually by 2-3\%. In 2020 the demand for zirconium may increase by $48-72 \%$ (compared to 2012), depending on the number of macro- and microeconomic factors. A similar trend is predicted by Credit Suisse experts (Hope 2012).

According to Iluka company (2016) the growth of demand for zirconium products will continue, but much slower. Thus, in the optimal case, the amount of consumption in 2020 will be higher on $35.3 \%$ than in 2013. In the worst case - $20 \%$ higher.

According to experts of DERA (2013) and Roskill (2015), the global production capacity of zirconium from 2016 to 2019 will be stable. The increase in production capacity is planned only in connection with the implementation of the projects which were mentioned above. The increase in production of Russian zirconium enterprises is not expected.

In 2020 the volume of zirconium production will decline sharply due to the depletion of large deposits in Australia (TZMI 2012) and forced closing the deposit down in the north part of Stradbruk Island (because of tightening environmental standards).

In the case of maintaining a high growth rate of zirconium products consumption, the market will form a surplus of more than 400 tons in 2020. In the case of slowing down in consumption (which is unlikely), the market, despite the decline in production in 2020, will remain a surplus of zirconium (150 tons).

In this situation the fields of South Africa, which can be implemented in 2020 are very promising. They are large enough, and are characterized by low cost of mining and ore dressing (Macdonald 2012).

Also, this surplus can bring some positive results for the Russian companies, in the case of implementation of new zirconium deposits. Thus, despite the current surplus in zirconium markets, in the long term is possible to enter on the world zirconium markets not only "Kovdorskiy GOK", but also several new Russian enterprises.

\section{Discussion and conclusion}

Zirconium is a valuable mineral resource, which, depending on the quality characteristics, may be used in many various industries, ranging from dentistry to nuclear power. At the same time about $80 \%$ of the zirconium products market has no substitutes.

Russia, having a large zirconium resource base (third in the world), develops it extremely slowly due to the lack of easy-to-mine surface and near-surface placer deposits. Promising areas for development of zirconium industry enterprises, in addition to the already explored deposits, are Volga district of Siberia, Baikal, Tambov region, Nizhny Novgorod region, Stavropol placer area.

Russia's share in world production of zirconium is extremely low (less than 1\%). The only Russian company, which carries out production and processing of zirconium is "Kovdorskiy GOK". All produced baddeleyite concentrate (about 95\%) is exported, while domestic demand is satisfied exclusively by import from Ukraine. Nevertheless, Russia occupies $18 \%$ of the world zirconium and its alloys products market.

Zirconium market is highly dynamic. Firstly, there is considerable variation in prices, which is explained by artificially high prices in the largest industry companies (in 2011-2012). Secondly, the consumption greatly depends on the situation in China, which is a major importer and exporter of zirconium products. Thirdly, there is a significant surplus of zirconium, reaching $15-20 \%$ of total production. 
Despite this, many companies actively work to start implementation of zirconium mining projects. Among them are three projects: “Tormin" (South Africa), "Kwale" (Kenya) and "Grand Cote" (Senegal). Moreover, it is planned to launch the "Dubbo Zirconia" project (Australia) in 2016.

Statistical data shows that the consumption of zirconium in the world increase annually by $3 \%$ (from 2005 to 2015). According to forecasts up to 2020, this growth will be several times higher. Despite this, in 2019 the production of zirconium will be significantly higher than its consumption. However, in 2020, after the exhaustion of the largest zircon deposits in Australia, an acute shortage of zirconium is predicted.

Thus, given the low competitiveness of most of Russian zirconium deposits, the main volume of production should provide domestic needs. Access to international markets is now extremely difficult and possible only in the case of a certain political influence, state support or international cooperation. One possible option is to develop a strategy for the development of zirconium enterprises aimed at the replacement, starting from 2020, production capacity of Australia on the global market. For example, in Europe, which will not be able to meet the growing demand for rareearth elements in the nearest future because of limited amount of scrap market (Cherepovitsyn et al. 2015).

\section{References}

Akimova A.V. et al. (2014) State report on the status and use of mineral resources of the Russian Federationin2013, Mineral Info, Moscow, Russia, 2014.URL:

http://www.mnr.gov.ru/upload/iblock/914/Report2014.pdf

Bwye C. (2014) Base Resources, Kwale Mineral Sands Project, JM Mineral Sands Conference, Melbourne, 2014. URL: http:/ / www.slideshare.net/informaoz/colin-bwye

Chalmers I. (2012) Dubbo Zirconia Project, Alkane Resources Ltd, 34th International Geological Congress, Brisbane, Australia, 2012. URL:

http://www.alkane.com.au/pdf/presentations/20120808.pdf

Cherepovitsyn A.E., Fedoseev S.V., Teslya A.B., Vyboldina E.Y. (2015) Analysis of production and consumption of rare-earth metals in the EU and the BRICS, Tsvetnye Metally, 5, 5-10. DOI: 10.17580/tsm.2015.05.01.

Volpato C.A.M., Luis Gustavo D., Altoé Garbelotto, Márcio Celso Fredel and Federica Bondioli (2011) Application of Zirconia in Dentistry: Biological, Mechanical and Optical Considerations, Advances in Ceramics - Electric and Magnetic Ceramics, Bio ceramics, Ceramics and Environment, Prof. Costas Sikalidis (Ed.), 2011, ISBN: 978-953-307-350-7, Intech, DOI: 10.5772/21630. URL: http://www.intechopen.com/books/advances-in-ceramics-electric-andmagnetic-ceramics-bioceramics-ceramics-and-environment/application-of-zirconia-indentistry-biological-mechanical-and-optical-considerations

TZMI (2012) Competent Person's Report for Base Resources Limited, TZMI, Australia, 2012. Available online:

http://www.baseresources.com.au/wp-content/files/583-586_Base_CPR_Final.pdf

DERA (2013) Zircon - insufficient supply in the future? Federal Institute for Geosciences and Natural Resources, Berlin, Germany, 2013. URL:

http://www.zircon-association.org/Websites/zircon/images/rohstoffinformationen-14.pdf

Deverell R., Kendall T., Shaw A., Stuart J. et al. (2013) Commodity Forecast. Back to the Future, Credit Suisse, Australia, 2013. URL:

https:// doc.research-and-

analytics.csfb.com/docView?language=ENG\&format=PDF\&document_id=1006377241\&sourc e_id=emcmt\&serialid=82WrSbQfSKNdtXD\%2bxQgUMqk7w9b4yKW3grN8otFRPTw\%3d

Didenko N., Kunze K., Skripnuk D. (2015) Russian Export Strategy and Social Sector: Consequences of Resource-Oriented Exports on Population of Russia, Mediterranean Journal of Social Sciences, 2015, Vol. 6, Iss. 5, Supplement 2. pp. 473-481 
EIR (2015) Mineral Commodities, Edison Investment Research Ltd, London, 2015. URL:

http:/ / www.edisoninvestmentresearch.com/research/report/mineral-commodities1

Elsner H. (2015) Heavy mineral of Economic Importance, Federal Institute for Geosciences and

Natural Resources, Hannover, Germany, 2015. URL:

http://www.bgr.bund.de/DERA/DE/Downloads/Heavy-Minerals-Economic-

Importance.html?_blob=publicatio

BGS (2015) European mineral statistic 2009-2013, British Geological Survey, Nottingham, 2015. URL:

http://www.bgs.ac.uk/mineralsuk/statistics/europeanStatistics.html

Thomson Reuters (2009) Factbox - nuclear industry and zirconium; Thomson Reuters, London, April 2009. URL:

http://www.reuters.com/article/2009/04/23/zirconium-nuclear-idUSLN78747920090423

Hope M. (2012) Mineral Sands Sector. Sector Review, Credit Suisse, Australia, 2012. URL:

https:/ / plus.credit-suisse.com/researchplus/ravDocView?docid=R3itjq

Iluka official web site. Available online: http://www.iluka.com/

Larichkin F.D., Vorobev A.G., Novoseltseva V.D., Popova G.I., Serebryannaya L.S. (2013) Zirconium: resources, markets, prospects, Tsvetnye Metally, 2013, 11, pp.17-21.

Lundberg M. (2011) Environmental analysis of zirconium alloy production, Uppsala Universität, Uppsala, 2011. URL:

http://www.diva-portal.org/smash/get/diva2:475527/FULLTEXT01.pdf

Macdonald A. (2011) Zircon substitution: myth or reality, Industrial Minerals Supplement, May 2011, 524, pp. $54-59$.

Macdonald A. (2012) Zirconium's cloudy future, Industrial Minerals, 2012, London, UK. ISSN: 00198544. P. 4.

Macdonald A., Chalmers I. (2014) Zirconium Oxide, Chemicals and Metal: Global Industry Markets and Outlook, Roskill, Australia, 2014, p. 146.

MacDonald A., Chalsmer I. (2013) Outlook for Zirconium and Rare Earth Materials until 2020, TZMI Congress 2013, Where the World's Titanium and Zircon Industries Meet, Hong Kong. URL: http://www.asx.com.au/asxpdf/20131114/pdf/42kv430swxb365.pdf

Mineral - Information-Analytical Center. URL: http:/ / www.mineral.ru/News/43547.html

USGS (2015) Mineral Commodity Summaries 2015, United State Geological Survey, Reston, Virgina, 2015. URL: http:/ / minerals.usgs.gov/minerals/pubs/mcs/2015/mcs2015.pdf

Roskill (2015) Mineral Sands Industry Warns on High-Grade Deposit Depletion; Roskill Information Service, Australia, 2015. URL: https://roskill.com/wp/wp-content/uploads/2015/09/Zir-PRApril-2015-headed.pdf

Porter R. (2014) Mineral Sands Industry. Fact Book; Iluka, 2014. URL:

http://www.iluka.com/docs/default-source/industry-company-information/the-mineral-sandsindustry-factbook-(feb-2014)

Reihl C., Schatz M., Zsak G. (2014) World-Mining-Data, International Organizing Committee for the World Mining Congresses, Vienna, 2014. URL:

http:/ / www.bmwfw.gv.at/EnergieUndBergbau/WeltBergbauDaten/Documents/WMD2014.pdf

RiC (2014) Global and China Zirconium Industry Report: 2013-2016, Research in China, Beijing, China, 2014 , p. 51.

Saridag S., Tak O., Alniacik G. (2013) Basic properties and types of zirconia: An overview, World Journal of Stomatology, 2013 August, 2(3), pp. 40-47. DOI: 10.5321/wjs.v2. i3.40.

Staff M., Munatswa A. (2014) Grande Cote Operations, Mineral Sand Mining, Melbourne, Australia, 2014. URL: https://www.offiziere.ch/wp-content/uploads/Grand-Cote-Operations-October2014.pdf

Stephenson P.R., Williams S., Webster R., Federici P. (2010) Grand Cote Mineral Sands Project, Technical Report for Mineral Deposits Mining Consultant Ltd, Canada, 2010. URL: 
http:/ / www.mineraldeposits.com.au/wp-content/uploads/2014/02/MDL-Grande-Cote-TechReport-29-Jul-10.pdf

Sutton S. (2015) Raw \& Manufactured Materials: 2015 Overview, I Advanced, 2015. URL:

http://www.ceramicindustry.com/articles/94420-raw-manufactured-materials-2015overview\#zirconium

Tiwari R. (2014) Germanium Industry and Zirconium Market View for Global and Chinese Regions, PR Newswire, Dallas, 2014. URL: http://www.prnewswire.com/news-releases/2016germanium-industry-and-zirconium-market-view-for-global-and-chinese-regions280005862.html

Vyboldina E., Cherepovitsyn A., Fedoseev S. and Tsvetkov P. (2016) Analysis of Export Restrictions and their Impact on Metals World Markets, Indian Journal of Science and Technology, Vol 9 (5), DOI: $10.17485 / \mathrm{ijst} / 2016 / \mathrm{v} 9 \mathrm{i5} / 87633$

Zirconium market (2012) International metallurgical research group, Ekateringurg, Russia, 2013. URL: http://www.metalresearch.ru/pdf/world_kaz_zr_market_2012_mr_content.pdf 